\title{
Effects of dietary excesses of vitamins A and D on some constituents of the blood of chicks
}

\author{
BY T. G. TAYLOR, * K. M. L. MORRIS† AND JEAN KIRKLEY* \\ Department of Physiology and Biochemistry, The University, Reading
}

$$
\text { (Received } 4 \text { April I968-Accepted I } \not 3 u l y \text { 1968) }
$$

1. Groups of chicks were given diets containing four levels of vitamins A and D, r, ro, 100 and 1000 times the basal level, in all sixteen combinations, with the object of investigating a possible antagonism between the two vitamins.

2. Only diets containing rooo times the basal level (approx. I700 times the dietary requirements) of one or both vitamins depressed growth and induced changes in the blood.

3. The packed cell volume was substantially reduced from 4 weeks of age in the chicks given the highest level of vitamin A. It is suggested that this was due to an effect of the vitamin on the fragility of the red cells and thus on their life span.

4. Chicks given the toxic level of vitamin $D$ showed an increase in plasma calcium and a decrease in plasma inorganic phosphorus. The highest level of vitamin A depressed plasma Ca without influencing plasma inorganic $\mathbf{P}$. Increasing amounts of vitamin A given in combination with the highest level of vitamin $D$ caused a progressive increase in the plasma inorganic $P$.

5. The highest level of dietary vitamin A significantly increased the activity in the plasma of three lysosomal enzymes: acid phosphatase, $\beta$-glucuronidase and arylsulphatase. Excess vitamin D given in conjunction with the basal level of vitamin A significantly depressed the plasma acid phosphatase and the activity of this enzyme increased with increasing amounts of vitamin A. Excess vitamin D had no influence on the other hydrolases studied.

6. A marked antagonism between the effects of excessive amounts of the two vitamins occurred only in respect of their actions on the plasma levels of $\mathrm{Ca}$, inorganic $\mathrm{P}$ and acid phosphatase, all of which are involved in bone metabolism.

Both vitamin $A$ and vitamin $D$ are toxic when fed in excessive amounts. The pathological effects of excess vitamin $A$ in chicks have been reported by Wolbach \& Hegsted (1952) and by Pudelkiewicz, Webster, Olson \& Matterson (1964). The most obvious clinical signs are a reduced growth rate, an encrustation of the eyelids and a reddening of the corners of the mouth. The eye and mouth lesions usually disappear at about Io days of age and thereafter the only clinical manifestations of the toxicity are reduced growth and a general appearance of unthriftiness. Bone fractures, which are among the most striking effects of vitamin A toxicity in rats (Davies \& Moore, I934), do not occur in chicks.

Little work has been carried out on the effects of excess vitamin $D$ in chicks but it is known that birds are far more resistant to vitamin $\mathrm{D}$ intoxication than mammals, in which the main lesions are calcareous deposits in the blood vessels and soft tissues, particularly the kidneys.

A number of biochemical effects of excess vitamin A have been attributed to the action of the vitamin on the membranes of cells and subcellular organelles, particularly the lysosomes. Treatment of lysosomes with vitamin $\mathrm{A}$ in vitro causes the release

* Present address: Agricultural Research Council's Poultry Research Centre, King's Buildings, West Mains Road, Edinburgh, 9.

+ Present address: Norwood Technical College, London, SE27. 
of their proteolytic enzymes (Dingle, I96r) and other hydrolases (Dingle, Sharman \& Moore, 1966) and the loss of mucopolysaccharides from cartilaginous limb-bone rudiments grown in organ culture in the presence of excess vitamin A (Dingle, Lucy \& Fell, I961) is probably due to the action of acid hydrolases liberated from the lysosomes by the vitamin. Experiments in vivo have shown that the liver lysosomes of rats treated with excess vitamin A are less stable than those of control animals (Dingle et al. 1966), but as far as we are aware no work has been published on the plasma activities of acid hydrolases in animals intoxicated with vitamin $A$, with the exception of that of Baker, Howell \& Thompson (1967) who observed an increase in the plasma level of acid phosphatase in hypervitaminotic chicks. There are reports in the literature, reviewed by Nieman \& Obbink (1954), that vitamin D may exert a protective influence against some of the harmful effects of excess vitamin $A$ and that large amounts of vitamin A may prevent many of the pathological changes of hypervitaminosis $D$ (Clark \& Bassett, 1962). The object of the present experiments was to investigate the possibility of an antagonism between excesses of the two vitamins in chicks, using packed cell volume and the activities in the plasma of some acid hydrolases as measures of the toxic effects of vitamin A; plasma levels of calcium and inorganic phosphorus were used as measures of the severity of hypervitaminosis D.

\section{EXPERIMENTAL}

\section{Animals and treatment}

Chicks. Male chicks (Thornber ' 404 ' strain) were placed in electrically heated tier brooders and fed the experimental diets from I day of age. The treatments were randomized throughout the brooders. Food and water were supplied ad lib. and the chicks were weighed weekly.

Diets. The composition of the basal diet, in parts by weight, was as follows: maize 55 , soya-bean meal 30 , dried skim milk 4 , dried yeast (unextracted) 5 , dried grass 3 , limestone flour $\mathrm{I}$, dicalcium phosphate $\mathrm{I} \cdot 5$, salt 0.5 . The calculated $\mathrm{Ca}$ and $\mathrm{P}$ contents of this diet were $\mathrm{r} \cdot 0$ and $0.8 \%$ respectively. To each $\mathrm{kg}$ diet were added $200 \mathrm{mg}$ manganese carbonate, 2600 i.u. retinol (Rovimix A325; Roche Products Ltd, Welwyn Garden City) and 500 i.u. cholecalciferol (dissolved in arachis oil). These basal additions represent the Agricultural Research Council ( 1963 ) estimates of requirements of chicks for vitamins $A$ and $D_{3}$ plus a margin of safety of approximately $70 \%$. Three levels of vitamin excess were fed, providing Io, 100 and 1000 times the basal level of each vitamin and these were added to the basal diet in a number of different combinations and in the same forms as in the basal diet. The four levels of vitamins $\mathrm{A}$ and $\mathrm{D}$ used were designated $\mathrm{IA}, 1 \circ \mathrm{A}, 100 \mathrm{~A}$ and $1000 \mathrm{~A}$ and $\mathrm{ID}, 10 \mathrm{D}, 100 \mathrm{D}$ and $1000 \mathrm{D}$, respectively.

Expt $\mathrm{r}$. This was a $4 \times 4$ factorial experiment with the four levels of vitamin A and four levels of vitamin $D$ fed in all combinations with twelve chicks on each treatment. Two chicks from each treatment were bled at 4, 5 and 6 weeks of age, and packed cell volume and plasma levels of $\mathrm{Ca}, \mathrm{P}$ and acid and alkaline phosphatases were determined. Total proteins were determined on the plasma of the 4 -week-old chicks. 
Expt 2. The only changes observed in Expt I were at the highest levels of dietary vitamin additions (I000 times basal level) and the effects of these diets were studied in greater detail in Expt 2. The eight dietary treatments were: control ( $\mathrm{r} A-\mathrm{ID}$ ), I A-I000 D, I0A-I000 D, $100 \mathrm{~A}-1000 \mathrm{D}, 1000 \mathrm{~A}-1000 \mathrm{D}, 1000 \mathrm{~A}-\mathrm{I} \mathrm{D}, 1000 \mathrm{~A}-\mathrm{I} 0 \mathrm{D}$, and $1000 \mathrm{~A}-100 \mathrm{D}$. Once again there were twelve chicks on each treatment and blood samples were taken from three chicks from each treatment at 2, 3, 4 and 5 weeks of age. In addition to the determinations made in Expt $I$, the activities in the plasma of $\beta$-glucuronidase, arylsulphatase and chitobiase ( $N$-acetyl- $\beta$-glucosaminidase) were determined, although it was not always possible to carry out all enzyme assays on all samples of plasma.

\section{Analytical methods}

All determinations were made on heparinized blood obtained from the jugular vein or on plasma derived from it.

Packed cell volume (PCV). Blood was centrifuged in Wintrobe tubes at $3200 \mathrm{~g}$ for $3^{\circ} \mathrm{min}$ at $5^{\circ}$. The values obtained in this way were not corrected for occluded plasma.

Plasma total Ca. The method described by Hertelendy \& Taylor (I96I) was used.

Plasma inorganic $P$. The procedure of Allen (1940) was carried out on trichloroacetic acid filtrates of plasma.

Total plasma proteins. The biuret method was used.

Plasma enzymes. Enzymes were assayed by the following methods: alkaline phosphatase $\left(E C_{3} \cdot \mathrm{I}_{3} \cdot \mathrm{r}\right)$, Bell (1960); acid phosphatase $\left(E C_{3} \cdot \mathrm{I}_{3} \cdot 2\right)$, Bell \& Siller (1962); $\beta$-glucuronidase $\left(E C_{3}\right.$.2.1.3r), Fishman, Springer \& Brunetti (1948) as modified by Levvy \& Marsh (1959); chitobiase ( $N$-acetyl- $\beta$-glucosaminidase ( $E C$ 3.2.1 .29)), Sellinger, Beaufay, Jacques, Doyen $\&$ de Duve (I960), using $p$-nitrophenyl 2-acetamido 2-deoxy- $\beta$-D-glucopyranoside as substrate; arylsulphatase ( $E C$ 3 . I .6. I), Roy (1953, 1958), using acetate buffer at $\mathrm{pH}_{4} .8$ (which we found to be optimum for chicken plasma) and 2-hydroxy-5-nitrophenyl sulphate $(3 \mathrm{~mm})$ as substrate: the incubation time was $14 \mathrm{~h}$ at $37^{\circ}$. Under these conditions most of the activity measured would have been due to arylsulphatase A (Bleszynski \& Dzialoszynski, 1965).

\section{RESULTS}

Growth. The only treatments that significantly influenced the growth rate of the chicks in Expt I were those in which rooo times the basal level of either vitamin A or D (or both) were fed, in which a marked depression of growth was observed. An example of this effect is shown in Table $I$ in which the mean live weights of the chicks at 5 weeks of age are given. Analysis of variance of these results showed significant differences due to both vitamin $\mathrm{A}$ and vitamin $\mathrm{D}(P<0.00 \mathrm{I})$ and there was also a significant interaction between the two vitamins $(P<0.00 \mathrm{r})$, reflecting the fact that the effect of a particular level of one vitamin varied according to the level of the other vitamin with which it was given. Thus, for example, the addition of $1000 \mathrm{D}$ to the diet containing the basal level of vitamin A significantly reduced the growth of the chicks, whereas it did not influence growth when added to the rooo A diet. It was not until the chicks were 2 weeks of age that a reduction in growth was noted in those groups 
fed the highest level of vitamin $A$ or $D$, which supports the view that the differences observed subsequently were treatment effects rather than effects due to position in the brooders. Depression in live-weight gain compared with controls was also observed in the experimental groups of chicks in Expt 2.

Table I. Expt I : mean live weights $(g)$ of chicks at 5 weeks of age given four levels of vitamin $A$ and four levels of vitamin $D$

(Means for ten chicks/treatment)

\begin{tabular}{|c|c|c|c|c|c|}
\hline \multirow{2}{*}{$\begin{array}{c}\text { Level of } \\
\text { vitamin A } \\
\text { ( } \times \text { basal level) }\end{array}$} & \multicolumn{4}{|c|}{ Wt with level of vitamin D ( $\times$ basal level) of: } & \multirow{2}{*}{$\begin{array}{c}\text { Mean } \\
\text { wt }\end{array}$} \\
\hline & $\mathbf{I}$ & Io & 100 & 1000 & \\
\hline $\mathbf{I}$ & $43^{8}$ & 459 & 445 & 264 & 402 \\
\hline I0 & 482 & 474 & 425 & 289 & 418 \\
\hline 100 & 449 & 493 & 456 & 368 & 442 \\
\hline 1000 & 306 & 239 & 276 & 278 & 275 \\
\hline Mean & 419 & 416 & 401 & 300 & - \\
\hline
\end{tabular}

SE of the difference between means in the body of the table $=24.2$. $\mathrm{SE}$ of the difference between vitamin $A$ and vitamin $D$ means $=12 \cdot 1$.

Table 2. Expt I: mean values for concentration $(\mathrm{mg} / \mathrm{1} 00 \mathrm{ml})$ of plasma calcium for chicks 4,5 and 6 weeks of age given four levels of vitamin $A$ and four of vitamin $D$

(Means for six chicks/treatment)

\begin{tabular}{|c|c|c|c|c|c|}
\hline \multirow{2}{*}{$\begin{array}{c}\text { Level of } \\
\text { vitamin } A \\
\text { ( } \times \text { basal level) }\end{array}$} & \multicolumn{4}{|c|}{ Concentration with level of vitamin $\mathrm{D}(\times$ basal level) of: } & \multirow{2}{*}{$\begin{array}{c}\text { Mean } \\
\text { concentration }\end{array}$} \\
\hline & I & 10 & 100 & 1000 & \\
\hline I & II.O & 10.5 & II. 3 & $13 \cdot I$ & I I 5 \\
\hline ro & $10 \cdot 8$ & 10.8 & 10.9 & $13 \cdot 1$ & II· 4 \\
\hline IOO & $10 \cdot 6$ & I I $\cdot 2$ & $10 \cdot 8$ & $12 \cdot 9$ & II. 4 \\
\hline I000 & $9 \cdot 6$ & $10 \cdot 0$ & $10 \cdot 3$ & 10.7 & $10 \cdot 2$ \\
\hline Mean & 10.5 & 10.7 & 10.8 & $12 \cdot 5$ & - \\
\hline
\end{tabular}

$\mathrm{SE}$ of the difference between means in the body of the table $=0.57$.

$\mathrm{SE}$ of the difference between vitamin $\mathrm{A}$ and vitamin $\mathrm{D}$ means $=0 \cdot 29$.

$P C V$. Results were obtained for chicks at 4, 5 and 6 weeks of age in Expt 1 , and at 2, 4 and 5 weeks in Expt 2. In both experiments differences from control values were observed only in the birds fed rooo times the basal level of vitamin $A$, in which a striking depression was observed from 4 weeks of age. Analysis of variance showed that this depression was significant $(P<0.001)$. No depression was observed at 2 weeks of age but it is possible that it may have occurred by the time the chicks were 3 weeks old. (Unfortunately no results were obtained for this stage.) The statistical analysis showed that vitamin D did not influence PCV, and the mean values for all twenty-four chicks fed vitamin A at I, IO, 100 and 1000 times the basal level in Expt I (birds 4, 5 and 6 weeks of age being grouped together) were, respectively, 28.8, 28.8, 27.9 and $2 \mathrm{I} \cdot 8$ : the standard error of the difference between these means, obtained from the analysis of variance, was 0.60 . Similar results were obtained in Expt 2. 
Plasma Ca. In Expt I dietary additions of to and soo times the basal level of vitamin $\mathrm{A}$ or $\mathrm{D}$ or both did not influence the plasma $\mathrm{Ca}$ at any age. The highest level of vitamin A significantly reduced the plasma $\mathrm{Ca}$ below the control value for the three lowest levels of vitamin D, while the diets containing I000 times the basal level of vitamin $D$ had a marked hypercalcaemic effect except when rooo times the basal level of vitamin A was also given (Table 2). Analysis of variance showed that the effects of both vitamins were significant $(P<0.001)$ and that the interaction between the vitamins was not significant. The mean level of plasma $\mathrm{Ca}$ in the chicks on the (I000A-1000D) treatment did not differ significantly from the control level. These results were confirmed in Expt 2, and it is clear that there was a marked antagonism between vitamin $A$ and vitamin $D$ when fed in toxic amounts in respect of their action on the level of plasma Ca.

Table 3. Expt I: mean values for concentration ( $\mathrm{mg} / \mathrm{roo} \mathrm{ml}$ ) of plasma inorganic phosphorus for chicks 4, 5 and 6 weeks of age given four levels of vitamin $A$ and four of vitamin $D$

(Means for six chicks/treatment)

\begin{tabular}{|c|c|c|c|c|c|}
\hline \multirow{2}{*}{$\begin{array}{c}\text { Level of } \\
\text { vitamin A } \\
\text { ( } \times \text { basal level) }\end{array}$} & \multicolumn{4}{|c|}{ Concentration with level of vitamin $D(x$ basal level) of: } & \multirow{2}{*}{$\underset{\text { concentration }}{\text { Mean }}$} \\
\hline & I & Io & 100 & 1000 & \\
\hline $\begin{array}{r}I \\
10 \\
100 \\
1000\end{array}$ & $\begin{array}{l}7 \cdot 6 \\
7 \cdot 6 \\
8 \cdot 2 \\
7 \cdot 4\end{array}$ & $\begin{array}{l}7 \cdot 5 \\
8 \cdot 2 \\
8 \cdot 4 \\
7 \cdot 8\end{array}$ & $\begin{array}{l}8 \cdot 0 \\
7 \cdot 9 \\
8 \cdot 5 \\
8 \cdot 0\end{array}$ & $\begin{array}{l}3 \cdot 8 \\
4 \cdot 6 \\
5 \cdot 4 \\
8 \cdot 1\end{array}$ & $\begin{array}{l}6 \cdot 7 \\
7 \cdot 1 \\
7 \cdot 6 \\
7 \cdot 8\end{array}$ \\
\hline Mean & $7 \cdot 7$ & $8 \cdot 0$ & $8 \cdot 2$ & $5 \cdot 4$ & - \\
\hline
\end{tabular}

$S E$ of the difference between means in the body of the table $=0.62$. $\mathrm{SE}$ of the difference between vitamin $A$ and vitamin $D$ means $=0.31$.

Plasma inorganic $P$. Analysis of variance of the combined results for chicks 4,5 and 6 weeks of age in Expt I (Table 3) showed that there were significant differences due to vitamin $\mathrm{A}(P<0.01)$ and to vitamin $\mathrm{D}(P<0.001)$ and that the interaction between the vitamins was also significant $(P<0 \cdot 001)$. Thus the two highest levels of vitamin A significantly increased the plasma inorganic $P$ and the highest level of vitamin $\mathrm{D}$ depressed it. Comparisons between subtreatments showed that the only groups of chicks in which significant changes from the control level occurred were those fed the highest concentration of vitamin $\mathrm{D}$ in combination with the three lowest levels of vitamin $A$, in which a reduction in the plasma $P$ was observed. The mean concentration of inorganic $P$ in the twelve groups of chicks at 4,5 and 6 weeks of age fed the three lowest levels of vitamin $D$ (a total of sixty-nine chicks) was $7 \cdot 9 \mathrm{mg} / \mathrm{I} 00 \mathrm{ml}$ and in the groups $1 \mathrm{~A}-1000 \mathrm{D}, 10 \mathrm{~A}-1000 \mathrm{D}, 100 \mathrm{~A}-1000 \mathrm{D}$ and $1000 \mathrm{~A}-1000 \mathrm{D}$, the means were, respectively, $3 \cdot 8,4 \cdot 6,5 \cdot 4$ and $8 \cdot 1 \mathrm{mg} / \mathrm{I} 000 \mathrm{ml}$. In these groups there was a roughly inverse relationship between the levels of plasma $\mathrm{Ca}$ and $\mathrm{P}$, and the antagonism between the two vitamins was once again apparent.

Total plasma proteins. None of the dietary treatments influenced these values.

Plasma alkaline phosphatase. The level of activity of this enzyme was very variable and no consistent effects of any of the dietary treatments were observed. 
Plasma acid phosphatase. Analysis of variance showed that the only treatments that had a significant influence on the activity of this enzyme were those in which one or both of the vitamins were fed at rooo times the basal level. Excess vitamin A substantially increased the activity of this enzyme in the plasma and vitamin D had no significant effect at this level of vitamin A. Excess vitamin D added to a diet containing the basal level of vitamin A significantly depressed the activity of acid phosphatase below the control level $(P<0 \cdot 00 \mathrm{I})$ and the activity increased as increasing amounts of vitamin A were added. These effects, which were not observed until the chicks were 4 weeks of age, are shown in Table 4 , in which the mean activities of plasma acid phosphatase in chicks at 4,5 and 6 weeks of age are given for the treatments common to both experiments.

Table 4. Mean activities (i.u.) of plasma acid phosphatase in chicks 5 and 6 weeks of age in Expt 1 and 4 and 5 weeks of age in Expt 2

(Means for nine or ten chicks/treatment)

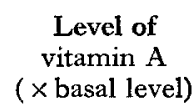

$x$
10
100
$1000 \dagger$
Activity with level of vitamin $\mathrm{D}(x$ basal level) of :

$\begin{array}{llll}\text { I } & 10 & \text { I00 } & 1000 \\ 28 \cdot I & - & - & 16 \cdot 9^{* * *} \\ - & - & - & 21 \cdot 01 \\ 47 \cdot 4^{* * *} & - & - & 27 \cdot 81 \\ & 48 \cdot 4^{* * *} & 47^{*} \cdot I^{* *} & 44 \cdot 9^{* * *}\end{array}$

*** Significantly different $(P<0.00$ I) from control (1 A, I D) means.

+ No significant differences within these four treatments.

I Significantly different $(P<0.001)$ from rooo A means.

Statistical treatment was by analysis of variance after log transformation, using the pooled SE of the means for tests of significance.

Plasma arylsulphatase and $\beta$-glucuronidase. No effects of the dietary treatments were observed until the chicks were 4 weeks of age, and then only in those groups fed the highest level of vitamin $A$, in which a marked elevation of both enzymes was observed. Analysis of variance showed that there was no significant effect due to vitamin $D$. To show the influence of excess vitamin $A$, the mean activities of both enzymes for all chicks 4 and 5 weeks of age fed Iooo times the basal level of vitamin A (twenty-four samples) have been compared with those of chicks receiving the three lowest levels of vitamin A (twenty-one samples). These means, with their standard errors, for ' $1000 \mathrm{~A}$ ' and 'less than $1000 \mathrm{~A}$ ' respectively were: arylsulphatase, $0.83 \pm 0.10$ and $0.45 \pm 0.04$ i.u.; $\beta$-glucuronidase, $0.19 \pm 0.01$ and $0.09 \pm 0.01$ i.u. For both enzymes the differences were highly significant $(P<0.001)$.

Plasma chitobiase. The activity of this enzyme was remarkably constant with all treatments.

\section{DISCUSSION}

The biochemical responses to excessive dietary intakes of the two vitamins may be grouped into three categories: (r) those affected by both vitamins and in which there was a marked antagonism between their actions (plasma $\mathrm{Ca}, \mathrm{P}$ and acid phosphatase), (2) those affected only by vitamin A (PCV, plasma arylsulphatase and $\beta$-glucuroni- 
dase), (3) negative responses (total plasma proteins, plasma alkaline phosphatase and chitobiase).

It appears therefore that the interactions between these vitamins are complex and not limited to a single mechanism.

An anaemia associated with a reduction in the red cell count is known to occur in rats suffering from hypervitaminosis A (Poumeau-Delille, 1943; Walker, Eylenburg \& Moore, 1947). Baker et al. (1967), however, did not observe a consistent effect of hypervitaminosis $\mathrm{A}$ on $\mathrm{PCV}$ in chicks at $2-4$ weeks of age, although they noted a fall at the age at which we first detected a marked depression in PCV ( 28 days). Papke (1937) suggested that the blood picture in rats suffering from hypervitaminosis A pointed to a hypochromic anaemia with hyperplastic bone marrow. The marrow of the chicks in this experiment was not examined, but Dr E. H. Hemsted, Royal Berkshire Hospital, Reading, kindly examined marrow smears from Japanese quail (Coturnix) fed a diet containing the same concentration of vitamin $\mathrm{A}$ as that present in the $1000 \mathrm{~A}$ diet. These quail showed a reduction in PCV similar to that in the chicks suffering from hypervitaminosis A. Whereas control smears contained large amounts of fat and were dominated by late normoblasts and mature heterophils, those from the quail intoxicated with vitamin A showed only small amounts of fat and consisted mainly of early normoblasts and immature heterophils.

The reduced $\mathrm{PCV}$ in the chicks given the I000 A diets could have been the result of an increase in the plasma volume, but the reduction was too great to make this explanation appear likely and it seems more probable that it was due to a reduction in the number of circulating red cells. Dingle \& Lucy (1962) have shown that erythrocytes suffer rapid haemolysis when incubated with retinol $(10 \mu \mathrm{g} / \mathrm{ml})$ in vitro at $37^{\circ}$, and it is suggested that excess vitamin A may have a similar effect in vivo. An increased fragility of the erythrocytes would be expected to reduce their life-span, to increase their rate of formation (indicated by hyperplasia of the marrow) and, if the rate of formation were unable to keep pace with the rate of destruction, to lead to a reduction in the number of circulating red cells and thus in the PCV. Vitamin D did not appear to influence this suggested course of events in these experiments.

The hypercalcaemic effect of excess vitamin $D$, one of its most characteristic actions, was shown in the chicks given the $1000 \mathrm{D}$ diet containing the three lowest levels of vitamin A. The hypocalcaemic effect of high levels of vitamin A, which we observed in the birds on the $1000 \mathrm{~A}$ diets, has been reported recently in rats by Belanger $\&$ Clark ( 1967 ). The physiological interaction between the two vitamins when both were administered at the highest level, resulting in a restoration of the plasma $\mathrm{Ca}$ to the control level, was most striking and it was noted also by Belanger \& Clark (1967); the mechanism of this interaction, however, is obscure.

A question that is provoked by the observation that diets high in vitamin $\mathrm{A}$ induce a hypocalcaemia in both rats and chicks is: "Why does not the parathyroid restore the plasma Ca to normal in this condition?' Any answer to this question must inevitably be highly speculative, but it is possible that bone does not respond to parathyroid hormone in hypervitaminosis $\mathrm{A}$, just as it fails to respond in vitamin D deficiency (Harrison, Harrison \& Park, I958). 
The hypercalcaemia observed in animals fed toxic levels of vitamin $\mathrm{D}$ is thought to be due both to increased absorption of $\mathrm{Ca}$ from the gut and to an increase in bone resorption. In the rat it is accompanied by a decrease in the plasma level of inorganic $P$ (Belanger \& Clark, I967), and this was also observed in the chicks on treatment I A$1000 \mathrm{D}$ in the present experiment. The plasma inorganic $\mathrm{P}$ increased progressively when the concentration of vitamin $A$ given together with the excess vitamin $D$ increased and the mean level in the chicks on treatment $1000 \mathrm{~A}-1000 \mathrm{D}$ did not differ significantly from the control (I A-I D) level (Table 3). Belanger \& Clark (I967) observed a significant decrease in the level of plasma inorganic $\mathrm{P}$ in rats intoxicated with vitamin $\mathrm{A}$, and a significant increase in those given excessive amounts of both vitamins, but neither of these effects was observed in the chicks in the present experiment.

In so far as the plasma levels of $\mathrm{Ca}$ and $\mathbf{P}$ reflect changes in bone metabolism it appears that excess vitamin $D$ exerts a similar action in both rats and chicks, but that excess vitamin $\mathrm{A}$ has a different effect in the two species. Hypervitaminosis $\mathrm{A}$ is associated with bone fractures in rats but not in chicks and the biochemical differences reported here may be related to the different clinical findings.

The increase in the activity of three lysosomal acid hydrolases (acid phosphatase, $\beta$-glucuronidase and arylsulphatase) in the plasma of the chicks given the $1000 \mathrm{~A}$ diets suggests that excess vitamin A causes the release of these enzymes from lysosomes in vivo just as it does in vitro (Dingle, 1961 ), but no information is available as to the precise tissue or tissues from which they were derived. It is surprising that there was no increase in the activity of chitobiase in the plasma of the $1000 \mathrm{~A}$ chicks, as this enzyme has a similar distribution and is released under the same conditions as $\beta$-glucuronidase and arylsulphatase (Beaufay, Jacques, Baudhuin, Sellinger, Berthet $\&$ de Duve, 1964; Vaes, 1965; Bowers \& de Duve, 1967). It is possible that it is readily inactivated in the general circulation or that it is rapidly excreted by the kidney. There is some support for the latter suggestion in the work of Morris (1967), who, in a study of the urinary excretion of enzymes in laying hens, found that approx. $\mathrm{I} 1$. plasma $/ 24 \mathrm{~h}$ was cleared of chitobiase compared with $10 \mathrm{ml}$ for $\beta$-glucuronidase and $400 \mathrm{ml}$ for arylsulphatase.

Baker et al. ( 1967 ) reported a decrease in the level of plasma alkaline phosphatase in chicks treated with excess vitamin A, although there was no indication whether or not this decrease was statistically significant, whereas we were unable to observe any consistent treatment effects on the activity of this enzyme. Variations both within and between groups of chicks were extremely large.

It appears from these experiments that there is no general antagonism between excess vitamin $A$ and excess vitamin $D$. There was, however, an antagonism in respect of the action of these vitamins on plasma $\mathrm{Ca}, \mathrm{P}$ and acid phosphatase, i.e. on some of the substances involved in bone metabolism, and it seems probable therefore that the main source of this particular acid hydrolase was the skeleton. Both osteoclasts and mature osteocytes are rich in acid phosphatase and it may be suggested that vitamin $A$ weakens the membranes of the lysosomes in these cells and that vitamin $D$ tends to stabilize them. 
We wish to thank Mr J. Pearson for the care of the chicks, Mr John Taylor for analytical assistance and $\mathrm{Mr} \mathrm{R}$. Morley Jones for statistical advice.

\section{REFERENCES}

Allen, R. J. L. (1940), Biochem. F. 34, 858.

Agricultural Research Council (1963). The Nutrient Requirements of Farm Livestock. No. I. Poultry. London: Agricultural Research Council.

Baker, J. R., Howell, J. McC. \& Thompson, J. N. (1967). Br. F. exp. Path. 48, 507.

Beaufay, H., Jacques, P., Baudhuin, P., Sellinger, O. Z., Berthet, J. \& de Duve, C. (1964). Biochem. $\mathcal{F}$. 92, 184 .

Belanger, L. F. \& Clark, I. (1967). Anat. Rec. 158, 443.

Bell, D. J. (1 960). Biochem. F. 75, 224.

Bell, D. J. \& Siller, W. G. (1962). Res. vet. Sci. 3, 2 r9.

Bleszynski, W. \& Dzialoszynski, L. M. (1965). Biochem. 9. 97, 360.

Bowers, W. E. \& de Duve, C. (1967). F. Cell Biol. 32, 339.

Clark, I. \& Bassett, C. A. L. (1962). F. exp. Med. II5, I47.

Davies, A. W. \& Moore, T. (1934). Biochem. F. 28, 288.

Dingle, J. T. (1961). Biochem. F. 79, 509 .

Dingle, J. T. \& Lucy, J. A. (1962). Biochem. \%. 84, 6 I I.

Dingle, J. 'T., Lucy, J. A. \& Fell, H. B. (1961). Biochem. F. 79, 497.

Dingle, J. T., Sharman, I. M. \& Moore, T. (I966). Biochem. F. 98, 476.

Fishman, W. H., Springer, B. \& Brunetti, R. (1948). F. biol. Chem. 173, 449.

Harrison, H. C., Harrison, H. E. \& Park, E. A. (1958). Am. F. Physiol. 192, 432.

Hertelendy, F. \& Taylor, T. G. (r96r). Poult. Sci. 40, 108.

Levvy, G. A. \& Marsh, C. A. (1959). Adv. Carbohyd. Chem, 14, 38 r.

Morris, K. M. L. (1967). Action of parathyroid hormone in the domestic fowl. $\mathrm{PhD}$ Thesis, University of Reading.

Nieman, C. \& Obbink, H. J. K. (1954). Vitams Horm. r2, 69.

Papke, W. (1937). Z. ges. exp. Med. ror, 648.

Poumeau-Delille (1943). C. r. Séanc. Soc. Biol. 137, 604.

Pudelkiewicz, W. J., Webster, L., Olson, G. \& Matterson, L. D. (1964). Poult. Sci. 43, I 557.

Roy, A. B. (1953). Biochem. $\mathcal{F} . \mathbf{5 3}, \mathbf{1 2 .}$

Roy, A. B. (1958). Biochem. F. 68, 5 r9.

Sellinger, O. Z., Beaufay, H., Jacques, P., Doyen, A. \& de Duve, C. (1960). Biochem. F. 74, 450.

Vaes, G. (1965). Biochem. F. 97, 393.

Walker, S. E., Eylenburg, E. \& Moore, T. (I947). Biochem. F. 4I, 575.

Wolbach, S. B. \& Hegsted, D. M. (1952). Archs Path. 54, 30. 